Report there is no trace of the proper working of the system.

3. Having written from memory, I readily apologise to Dr. Rolleston for inadvertently confounding his quotation from Dr. Mouat with a like opinion expressed, as I believe, in that gentleman's first report, in which report my own quotation from Dr. Mouat will be found. But does Dr. Rolleston indeed throw doubt on a favourable opinion, confirmed by the Indian, and subsequently by other Governments? The Colonial Secretary sent copies of these reports to every Colonial Government. The Canadian Government has largely adopted the system in public institutions; besides recently reprinting, through the Secretary of State for the Provinces, my "National Health and Wealth" both in English and French. Can, then, Dr. Rolleston's inference, at the close of his second letter, be just? Can there be so much danger in this system? Are these various official bodies, -is the Registrar-General (Quarterly Returns, July 31, 1867),--are those who passed the New Sanitary Amendment Act (July 31, 1868) "not in their senses," because they prefer a system which, if rightly worked, does deodorise and disinfect, to a system which cannot deodorise and does not pretend to disinfect? I am, Sir, yours faithfully,

Fordington Vicarage, April 3rd, 1869. HENRY MOULE.

\section{THE BIDDENDEN MAIDS.}

\section{To the Editor of THE LaNCEx.}

SiR,-After a recent visit to the Siamese twins, I read with great interest the description in THE LANCET.

Mr. W. Leech, of Moorgate-street, had previously directed my attention to an extract from "Pulleyn's Miscellany," a remarkable compendium published in 1828, in which mention is made of two sisters who (if the story is a true one) seem to have been united in a manner somewhat similar to that in which Messrs. Chang and Eng are connected. As the subject is exciting considerable interest at the present time, and Pulleyn's curious book is rare and not often seen, I venture to put the extract before your readers.

"The small town of Biddenden, in Kent, which is about four miles from Tenterden, is famous for a custom of giving to the parishioners, and even strangers, on Easter Sunday, 1000 cakes, impressed with the figure of two females joined together. The origin of the custom is thus related:-

"In the year 1000, at Biddenden, in Kent, were born Elizabeth and Mary Chulkhurst, joined together by the hips and shoulders, and who lived in that state thirty-four years; at the expiration of which time one of them was suddenly taken ill, and after a short period died. The surviving one was advised to be separated from the corpse which she absolutely refused, by saying these words, "As we came together, we will also go together ;' and about six hours after her sister's decease she was taken ill and died also. A stone near the rector's pew, marked with a diagonal line, is shown as the place of their interment.

"It is further stated that, by their will, they bequeathed to the churchwardens of the parish of Biddenden, and their successors for ever, certain pieces or parcels of land in the parish, containing about 20 acres, which is hired at 40 guineas per annum; and that in commemoration of this wonderful phenomenon of nature, the rolls, and about 300 quartern loaves, and cheese in proportion, should be given to the poor inhabitants of the parish."

I am, Sir, your obedient servant,

Nottingham, Feb. 22nd, 1869. WM. TINDAL Robertson, M.D.

\section{RETIREMENT OF PRISON SURGEONS.}

\section{To the Editor of THE LANCET.}

SIR,-As I am the individual alluded to in your article on the Superannuation of Prison Surgeons, I feel myself called upon to state the circumstances, hoping that the question will be taken up by the profession as a public one, in which all gaol officials are deeply interested.

I served the office of surgeon to the county gaol and kouse of correction at Bury St. Edmunds for twenty-five years. In 1867 I retired from practice, principally in consequence of my health failing; and, as a matter of course, resigned the appointment. Shortly after I applied for the pension, to which I consider I am fairly and justly entitled, as I was never upon any one occasion, during the twentyfive years, complained of in the execution of my duties. I have made several applications to the visiting magistrates and to the magistrates in Quarter Sessions assembled, but without effect. They will neither grant me my pension, nor state the reason for not doing so.

Now, Sir, if the section in the Act of Parliament is to be considered as a dead letter, not to be acted upon, surely it ought to be expunged from the Act without delay, so that the officers of prisons should not be acting under false impressions, and run the chance of being treated as I have been. I am, Sir, your obedient servant,
Dover, March 13th, 1869. Chardes C. SMrTh, F.R.C.S.E.

\section{BIRMINGHAM.}

(FEOM OUR OWN CORRESPONDENT.)

THE first winter session of the new medical school at the Queen's College has been most satisfactory. The lecture theatres have been well filled, and the dissecting-room abundantly supplied. In this last respect the school has been more fortunate than many, for although the supply was always fair when two schools existed, it has this year been unusually good. The amalgamation has certainly proved a success in many ways. It has rendered the enforcement of discipline more easy; and, if the experience of a single year may be taken, it has inspired both the professors and the students with new energy, This energy has extended beyond the College walls, and favourably influenced the clinical teaching at the hospitals.

Heretofore each hospital trusted to its own school for a supply of students; now that there is but one school, and that neutral, a healthy competition in the most important branch of teaching has been engendered. The desirability of giving class prizes has lately been under the consideration of the Professors at the College, and a new scheme for the Honour Examinations devised. Instead of giving a prize in each class, and allowing any of the students of the class to compete, a general prelininary examination in all the subjects of each year will in future be held, and only those students allowed to compete for class-prizes who have passed in all the subjects of the general examination. By this means it is hoped that the cultivation of one subject to the exclusion of the other's may be avoided. The scheme seems a good one, but it very naturally occurs that all such matters would be better regulated by a central body, combining the experience of all the lecturers in the kingdom. Why the Medical Teachers' Association, by excluding provincial schools, has deprived itself of this position, it is difficult to understand.

At the General Hospital, on the last operating day of the session, the students witnessed ovariotomy, performed by Mr. Goodall on a case of Dr. Foster's. The patient was twenty-three years of age; the cyst, which had existed for twenty months, was single, and free from adhesions, as previously anticipated. The incision was three inches long, and the cyst escaped from the abdomen before it was completely emptied. No intestine was seen during the operation; the pedicle was secured by a clamp. The patient was fed by nutritive enemata for three days after the operation. A little sickness occurred on the first day, but no other bad. symptom retarded the recovery. At the same hospital, Dr. F'oster has been making some observations on Diabetes, no less than four cases having been under his care at one time. Peroxide of hydrogen (ozonic ether) has been found useless, and ordinary ether equally so. But some good results have been obtained by the use of ergot, which, in large doses long continued, has been followed by a marked diminution in the quantity of sugar. Dr: Foster has also had a typical case of Duchenne's paralysis with muscular hypertrophy, in a boy aged nine years.

At the annual meeting of the Queen's Hospital, held recently, it was decided to abandon the midwifery department. The obstetric surgeons some little time since asked for the 